Journal : JMMR (Jurnal Medicoeticolegal dan Manajemen Rumah Sakit), 9 (1): 30-40, April 2020

Website : http://journal.umy.ac.id/index.php/mrs

DOI $\quad$ : https://doi.org/10.18196/jmmr.91114

\title{
Enhancing Nurse Performance by Improving Quality of Work Life, Knowledge and Attitude
}

\author{
Nur Hidayah ${ }^{1}$, Alviane Tiara Putri ${ }^{2}$ \\ ${ }^{1}$ Author Correspondence: nurhidayah@umy.ac.id \\ ${ }^{I}$ Master of Hospital Administration, Universitas Muhammadiyah Yogyakarta, Indonesia \\ ${ }^{2}$ Rumah Sakit Islam Al Ikhlas, Malang, Central Java, Indonesia

\begin{tabular}{lll}
\hline I N D E X I N G & A B S T R AC T \\
\hline Keywords: & Cases of medical errors in health care services are serious problems. In Indonesia, the incidence of \\
Knowledge; & work accidents still often afflicts nurses in hospitals. The prevalence of patient safety is still high. The \\
Attitude; & research aimed to analyze the factors that affected nurse performance in the application of the patient \\
Work-Life; & safety system at the hospital. The sampling technique employed a total sampling of 40 people. Data \\
Nurse; & analysis functioned the Partial Least Square. The results shew: a) The knowledge influenced on the \\
Performance. & nurse performance and the work-life quality, b) The attitude of nurses affected the quality of work- \\
& life, but did not affect performance. The knowledge was the most robust variable affected \\
& performance. Conclusion: to improve nurse performance, a hospital should enhance the knowledge, \\
& attitudes, and nurse quality work of life.
\end{tabular}

Kata kunci: $\quad$ Kasus kesalahan medis dalam layanan perawatan kesehatan adalah masalah serius. Di Indonesia, Pengetahuan; insiden kecelakaan kerja masih sering menimpa perawat di rumah sakit. Prevalensi keselamatan Sikap; $\quad$ pasien masih tinggi. Penelitian ini bertujuan untuk menganalisis faktor-faktor yang mempengaruhi Kehidupan Kerja; $\quad$ kinerja perawat dalam penerapan sistem keselamatan pasien di rumah sakit. Teknik pengambilan Perawat; sampel menggunakan total sampling 40 orang. Analisis data menggunakan Partial Least Square. Hasil Kinerjapasien. $\quad$ menunjukkan: a) Pengetahuan mempengaruhi kinerja perawat dan kualitas kehidupan kerja, b) Sikap perawat mempengaruhi kualitas kehidupan kerja, tetapi tidak mempengaruhi kinerja. Pengetahuan adalah variabel yang paling kuat mempengaruhi kinerja. Kesimpulan: untuk meningkatkan kinerja perawat, rumah sakit harus meningkatkan pengetahuan, sikap, dan kualitas kerja perawat.

(C) 2020 JMMR. All rights reserved

Article History: Received 2020-03-23; Revised 2020-04-23; Accepted 2020-04-27

\section{INTRODUCTION}

Patient safety is a very important topic in the field of health care today. The challenge for hospitals is the increasing number of patient safety incidents (Brasaite dkk., 2016). There are still many medical error cases in health care services - medical error effect on patient safety (Elden \& Ismail, 2016). Unsafe medication practices and medication errors are a leading cause of injury and avoidable harm in health care systems across the world. Globally, WHO estimated the cost associated with medication errors at USD 42 billion annually (WHO, 2017). In Indonesia, patient safety in a hospital has been regulated by the Government Republic of Indonesia since the year 2011. The Patient Safety Incidence (PSI) rates were still high, but only a few were reported due to a lack of understanding of the officers to the importance of the report. The implementation of the PSI reporting system is not optimal because the officers fear to report the incident and the high workload of health workers. Reporting of PSI that does not cause patient injury tends to not reported also (Gunawan dkk., 2015). Even though one of the basic principles in health care is patient safety, studies in developed countries found that during health care, the large number of 
patients harmed, either injury permanently, they suffer more seriously and have to stay for a long time in health care, or even death. Based on recent research in the United States, medical errors are the third cause of death. Lately, in the United Kingdom, approximately patient harm is reported every 35 seconds (WHO, 2017).

In general, nurses occupied the majority of health professions in hospitals; thus, nurses play crucial roles in health services and hold the responsibility of delivering care to patients professionally and safely. Therefore, the ability to prevent and minimize errors they may make is also imperative (Hariyati et al, 2017),(Andri \& Soewondo, 2018). This research focuses on nurse performance, which needs to be improved. The nurse position is at the frontline in health care services. They are always present around the patient room. They also communicate with the patient and their families and also interact with all the health care team. Assessment of nurse performance plays a vital role in guaranteeing high-quality clinic care to achieve desired patient outcomes (Kahya \& Oral, 2018). Patient safety systems in a hospital require high nurse performance on the implementation of the patient safety systems in a hospital.

Currently, the environment in healthcare is increasingly fraught with patient problems and concerns. Reduction of payment, workload, high turnover, and professional conflicts has caused an environment full of stress for healthcare providers and influence patient safety. (Mwachofi dkk., 2011). The health care environment influences the quality of work-life (QWL). In evaluating the quality of health care quality of nursing care is considered an essential aspect in evaluating the quality of health care. The quality of nursing and health care directly influence job satisfaction among nurses and the quality of the nurse's work life. The rapidly changing health care environment has had an impact on the nursing work environment, workload, and quality of nursing work life. Quality of work-life influences works performance (Wara dkk., 2018). Some research identified that the quality of work-life affected performance. (Chan \& Wyatt, 2007). Seven predictor QWL are: 1) the degree the supervisor treat with respect, and trust to the employees; 2 ) in daily work routine, there are varieties; 3) the work are challenges; 4) There is a pathway to carrier opportunity in the future from the currently works; 5) the outside of work-life affect the life at work; 6) the work that employees do contribute the life of society (Levine dkk., 1984).

Research that the majority of respondents have good knowledge, agreeing that patient safety is very important, if there are nurses who make unintentional mistakes, they will not be blamed (Almaramhy dkk., 2011). While knowledge and attitude of Health Care Professional workers have a significant relationship towards Patient Safety and Skills for Safe Patient Care (Brasaite dkk., 2016), a previous study also noted that there was a relationship between nurses knowledge and the implementation of patient safety, and there was a relationship between nurses' attitudes and the implementation of patient safety (Bawelle etc., 2013). The six research hypotheses $(\mathrm{H})$ in the application of patient safety system at the hospital:

H1: The nurse knowledge effects on the nurse quality of work-life

$\mathrm{H} 2$ : The nurse knowledge effects on nurse performance

H3: The nurse attitude influences the quality of work-life

$\mathrm{H} 4$ : The nurse attitude influences nurse performance

H5: The nurse quality of work-life impacts on the nurse performance

H6: The nurse knowledge effect on nurse performance through the quality of work-life 
H7: The nurse attitude effect on nurse performance through the quality of work-life

\section{RESEARCH METHOD}

This research was quantitative research with a cross-sectional research design. The Objects of this research covered four variables, namely knowledge, attitudes, quality of worklife, and nurse performance in the application of patient safety systems in the hospital. Subjects of this study are nurses who work at the X Hospital. That hospital is located in the Province of Central Java, Indonesia. This research was done in July 2017. The population of this research was 40 nurses, and the sampling technique chose a total sampling technique, which means the sample size is the same as the population. The independent variables were nurse knowledge (X1), and nurse attitudes (X2), the intervening variable was the quality of work-life of the nurse (Y1), and the dependent variable was nurse performance (Y2).

The validity test determines whether data is valid or not. The criteria are if $r$-result is positive, and $r$-count $>r$-table, then the data is considered valid. Conversely, when $r$-result is negative, and r-counts < r-table, then the data is considered invalid. The reliability test is to show the stability and consistency of a measuring instrument. Reliable data means that the data can be trusted. The reliability test in this study uses the value of Cronbach Alpha. A research instrument would be said to be reliable if the reliability coefficient $>0.6$ (Ghozali, 2013). Data analysis uses Structural Equation Modeling (SEM) with Partial Least Square (PLS) data analysis tools, and the Regression Weight technique to examine how much influence among variables. SEM is multivariate analysis techniques to examine the relationship among complex variables, both recursive and non-recursive, to obtain a comprehensive picture of the overall model. (Ghozali, 2013) A complete SEM modeling consists of Measurement Model and Structural Model. The measurement model is to confirm the indicators of latent variables and describe the causality of the relationship among variables, while the structural model is to shape or explain causality between factors. The difference between SEM and other multivariate techniques is that the input data are in modeling and estimation. SEM only uses matrix Variance/Covariance/ correlation matrix as input data for all estimates made.

There are three steps to construct a complete SEM model. First, searching for a model that has strong theoretical justification, then empirically validates it through computational SEM programs. SEM is to confirm a theoretical model through empirical data, and SEM is not to produce a model, so, without a strong theoretical basis, SEM cannot be adopted. Second, with the theoretical model that has been established in the previous step, then the available model is depicted on a path diagram. By the path diagram, the researcher can quickly identify which the independent variables and the dependent variables are. Third, evaluating the model; In PLS, the model to be evaluated includes a measurement model (external model) and a structural model (internal model). Evaluating the measurement model includes testing of the validity of convergence, testing of the validity of discriminant, and testing of the validity of internal consistency of reliability. According to Chin, quoted by Imam Ghozali (13), testing the significance of parameters are not needed, because PLS does not assume a certain distribution for parameter estimation.

The measurement model with reflective indicators is evaluated by convergent validity and discriminant validity of the indicator. In the testing of the validity of convergence, if the 
value of AVE (for all indicators) > 0,7 means valid, except according to "the rule of thumbs" that mentions if the value of AVE $>0,55$ it can also be categorized valid. In the testing of the validity of discriminant, if the value of the root squared of AVE > correlation value among the constructs, meaning that good discriminant validity is achieved. In the testing of validity of internal consistency of reliability, if composite reliability value $>0.8$, it means high reliability, and if composite reliability value $>0.70$, it is still said to be excellent reliability, and if composite reliability value $>0.60$, it can still be accepted if the indicator validity requirements in the model are good, and if the construct of correlation with the subject of measurement (for each indicator) is greater than the size of the other constructs, then the latent construct predicts the indicator is better than the other constructs.

In testing structural models, PLS begins by looking at the R-square for each dependent variable whose interpretation is the same as the interpretation in regression. Changes in the value of R-square can be to assess the influence of certain independent latent variables on latent dependent variables and whether they have substantive or not. Evaluating the structural model includes testing of the Coefficient of Determination (R2) for latent endogen variables and testing of the coefficient of the path (p). The testing of R2 uses the criteria, if the value of R2 equal or higher than 0,67 indicates a good model if the value of R2 equal or higher than 0,33 indicates a moderate model and if $\mathrm{R} 2$ equal to or higher than 0,19 indicate a weak model. The testing of the coefficient of the path (p) uses the criteria; if $p$-value $>p$ table, the path (p) coefficients are indicated significant. The $\mathrm{p}$ test is to test the significance of constants and independent variables, whether it influences the value of the dependent variable or not, while the coefficient of determination is to show the effect of all independent variables on the dependent variable in percentage.

\section{RESULT AND DISCUSSION}

A general profile of the respondent as follows:

Table 1. The Characteristic of Respondents

\begin{tabular}{|c|c|c|c|}
\hline No. & \multicolumn{1}{|c|}{ The Characteristic } & Frequency & Percentage \\
\hline 1. & Gender & & \\
\hline & a. Male & 12 & 30,0 \\
\hline & b. Female & 28 & 70,0 \\
\hline 2. & Age & & 40,0 \\
\hline & a. <25 years & 22 & 55,0 \\
\hline & b. 25 - 30 years & 2 & 5,0 \\
\hline & c. > 30 years & 40 & 100,0 \\
\hline & Total & & \\
\hline
\end{tabular}

Source: Research Data

The most respondent is female 28 people (70\%), and the respondents are still young $(95 \% \leq$ 30 years). 
Data Analyzes used PLS:

Tabel 2. Latent Variable Correlations

\begin{tabular}{|l|c|c|c|c|}
\hline & $\mathrm{X} 1$ & $\mathrm{X} 2$ & $\mathrm{Y} 1$ & $\mathrm{Y} 2$ \\
\hline The nurse knowledge (X1) & 1,000 & & & \\
\hline The nurse attitude (X2) & 0,426 & 1,000 & & \\
\hline The nurse quality of work-life (Y1) & 0,564 & 0,784 & 1,000 & \\
\hline The Nurse Performance (Y2) & 0,653 & 0,739 & 0,824 & 1,000 \\
\hline
\end{tabular}

Source: Output Data Analyze of PLS, 2018

The value of correlation is a continuum from zero (0), mean very weak correlation to one (1), mean very strong correlation. If there are three categories, weak correlation $(0-$ $0,33)$, medium correlation $(0,34-0,66)$, and strong correlation $(0,67-1)$, the correlation between the nurse knowledge and the nurse quality of work-life and the nurse performance are medium, and the correlation between the nurse attitude and the nurse quality of worklife and the nurse performance are strong. As well the correlation between the quality of work-life and the nurse performance is strong. As a result, when the hospital improves the nurse knowledge, the nurse attitude, and quality of work-life, then the nurse's performance also will be better than before based on the strength of the correlation of the variables.

\section{Validity and Reliability Test}

\section{Convergent Validity Test}

All items were included in the model test. The result of the convergent validity calculation as follows: The nurse knowledge construct consists of 21 items; there are ten items $<0,5$. The nurse attitude constructs consists of 24 items; there are ten items $<0,5$. The quality of work-life has 21 items; there are nine items $<0,5$. The nurse performance constructs consists of 28 items; there are four items $<0,5$. The items with score $<0,5$ are not valid, so they have to be excluded from the model, then the constructs are calculated again. The result of convergent validity test, with criteria AVE, and after removing all of not valid items is shown in table 3

Table 3. Convergent validity Test with criteria AVE

\begin{tabular}{|l|c|}
\hline \multicolumn{1}{|c|}{ Variables } & The average variance extracted (AVE) \\
\hline Knowledge of nurse & 0,500 \\
\hline Attitude of nurse & 0,422 \\
\hline Quality of work-life of a nurse & 0,469 \\
\hline Performance of nurse & 0,430 \\
\hline
\end{tabular}

Source: Output SmartPLS, 2018

\section{Discriminant Validity Test}

Result of discriminant validity test, with the criteria root, squared AVE, and after removing all of the not valid items is shown in table 4 below: 
Table 4. Discriminant validity Test with criteria Root Squared AVE

\begin{tabular}{|l|c|c|}
\hline \multicolumn{1}{|c|}{ Variables } & AVE & Root squared AVE \\
\hline Knowledge of nurse & 0,500 & 0,707 \\
\hline Attitude of nurse & 0,422 & 0,650 \\
\hline Quality of work-life of a nurse & 0,469 & 0,684 \\
\hline
\end{tabular}

Source: SmartPLS output, 2018

The square root of AVE > AVE value, so that the discriminant validity is considered fulfilled.

Result of Internal Consistency Reliability test, with criteria Cronbach's Alpha EF Composite Reliability, is shown in table 5 below.

Table 5. Internal Consistency Reliability test with criteria Cronbach's Alpha \& Composite Reliability

\begin{tabular}{|l|c|c|}
\hline \multicolumn{1}{|c|}{ Variables } & Composite Reliability & Cronbach's Alpha \\
\hline Knowledge of nurse & 0,915 & 0,898 \\
\hline Attitude of nurse & 0,914 & 0,897 \\
\hline Quality of work-life of a nurse & 0,918 & 0,903 \\
\hline Performance of nurse & 0,947 & 0,941 \\
\hline
\end{tabular}

Source: SmartPLS output, 2018

Composite Reliability and Cronbach's Alpha in all constructs have a value of $>0.70$, which means they have shown high instrument consistency and stability so that the instrument reliability is considered fulfilled. The result of the $R$ square value is shown in table 6 below.

Table 6. $\mathrm{R}$ square value

\begin{tabular}{|l|c|}
\hline \multicolumn{1}{|c|}{ Variables } & R Square \\
\hline Knowledge of nurse & \\
\hline Attitude of nurse & 0,676 \\
\hline Quality of work-life of a nurse & 0,760 \\
\hline Performance of nurse & \\
\hline
\end{tabular}

Source: SmartPLS output, 2018

R-square for the variable of quality of work-life is 0.676 means that the quality of worklife is explained by variables of knowledge and attitudes $67.6 \%$. While R-square for the variable of nurse performance of 0.760 means that the nurse's performance is explained by variables of knowledge, attitudes, and quality of work-life as of $76 \%$. The value of $t$-statistics shows the result of hypothesis testing. If the value of $t$ statistics $>t$ table, then the hypothesis will be accepted. Estimating t-statistics can be seen in the result for the inner weight, which is presented in table 7 . 
Table 7. Path Coefficients (Mean, STDE, T-Values)

\begin{tabular}{|l|c|c|c|c|c|}
\hline \multicolumn{1}{|c|}{ Path between variables } & $\begin{array}{c}\text { Original } \\
\text { Sample } \\
(\mathbf{O})\end{array}$ & $\begin{array}{c}\text { Sample } \\
\text { Mean } \\
(\mathbf{M})\end{array}$ & $\begin{array}{c}\text { Standard } \\
\text { Deviation } \\
(\text { STDEV) }\end{array}$ & $\begin{array}{c}\text { T } \\
\text { Statistics } \\
(\mathbf{O} / \text { STER }\end{array}$ & $\begin{array}{c}\mathbf{P} \\
\text { Values }\end{array}$ \\
\hline Knowledge $\rightarrow$ Nurse Performance & 0,228 & 0,244 & 0,081 & 2,820 & 0,005 \\
\hline Knowledge $\rightarrow$ Quality of work life & 0,282 & 0,286 & 0,101 & 2,784 & 0,006 \\
\hline Attitude $\rightarrow$ Nurse Performance & 0,077 & 0,098 & 0,139 & 0,553 & 0,580 \\
\hline Attitude $\rightarrow$ Quality of work life & 0,649 & 0,669 & 0,145 & 4,488 & 0,000 \\
\hline Quality of work Life $\rightarrow$ Nurse Performance & 0,510 & 0,501 & 0,119 & 4,279 & 0,000 \\
\hline
\end{tabular}

Source: SmartPLS output, 2018

To test the hypothesis, using a 5\% significance level, with $\mathrm{t}$ table equal to $1,960(\mathrm{~N}=40)$.

$\mathrm{H1}$ : On the pathway between knowledge to quality of work-life shows that $t$ count is 2.784 . Due to count $>\mathrm{t}$ table, then the hypothesis $(\mathrm{H} 1)$, which states that "the nurse knowledge influences the nurse quality of work-life," is supported.

$\mathrm{H} 2$ : On the pathway between knowledge to performance shows that $\mathrm{t}$ statistic ( $\mathrm{t}$ count) is 2.820. Due to $t$ count $(2.820)>t$ table (1.960), then the hypothesis $(H 2)$, which states that "the nurse knowledge influences the nurse performance," is supported.

H3: On the pathway between attitude to the quality of work-life shows that $\mathrm{t}$ count is 4,488 . Due to $t$ count $>t$ table, then the hypothesis $(\mathrm{H} 3)$, which states that "the nurse attitude influences the quality of work-life" is supported.

H4: On the pathway between attitude to the nurse performance shows that $t$ count is 0,553 . Due $t$ count $<t$ table, then the hypothesis (H4), which states that "the nurse attitude influences the nurse performance," is not supported.

H5: On the pathway between the quality of work-life to performance shows that $t$ count is 4,279 , then the hypothesis (H5), which states that "the quality of work-life influences the nurse performance," is supported.

H6: Thus, if the pathway between the nurse knowledge to quality of work-life and be continued to the nurse's performance is linked, so the hypothesis which states that "the nurse knowledge influences performance through the quality of work-life" is also supported.

H7: As well, if the pathway between the nurse attitude to the quality of work-life and be continued to the nurse's performance is linked, so the hypothesis which states that "the nurse attitude influences performance through the quality of work-life" is supported too.

Testing the Effect of Intervening Variables are shown in table 8 below: 
Table 8. The effect of Intervening variables

\begin{tabular}{|l|c|c|c|}
\hline \multicolumn{1}{|c|}{ Interaction } & value & P-value & $\begin{array}{c}\text { Type of } \\
\text { influences }\end{array}$ \\
\hline Knowledge of nurse to performance of nurse & 0,228 & 0,005 & direct \\
\hline $\begin{array}{l}\text { Knowledge of nurse to quality of work-life of a } \\
\text { nurse }\end{array}$ & 0,282 & 0,006 & direct \\
\hline The attitude of a nurse to performance of nurse & 0,077 & 0,580 & direct \\
\hline $\begin{array}{l}\text { The attitude of a nurse to quality of work-life of } \\
\text { a nurse }\end{array}$ & 0,649 & 0,000 & direct \\
\hline Knowledge of nurse to performance of nurse & 0,144 & 0,005 & indirect \\
\hline The attitude of a nurse to performance of nurse & 0,331 & 0,007 & indirect \\
\hline
\end{tabular}

Source: SmartPLS output 2018

So, it can be concluded that direct influences are stronger than indirect influences. Variable of the nurse knowledge synergize with the variable of the quality of work-life to improve nurse performance, but the variable of the nurse attitudes needs the variable of quality of work-life in order to improve nurse performance.

\section{DISCUSSION}

The highest score, from the respondent's answer about patient safety, is on the indicator that state the patient's risk assessment falls during treatment, means that most nurses have realized the importance of risk assessment and prevented unexpected events. Increasing nurses' knowledge can be done in several ways, namely through socialization, ongoing training, and learning to a higher level of education. By increasing nurses' knowledge will increase their confidence and dare to take a stand towards something that will ultimately affect behavior. Ida Sukesi et al. (2015) showed that knowledge has a significant effect on the performance in the implementation of patient safety, meaning, the higher the knowledge, the performance of patient safety implementation increases. Nurses who have extensive knowledge will act according to the knowledge they have; they are aware of the limits of right or wrong for actions that can cause accidents to patients so that they will be more careful in working to implement a patient safety system at the hospital. Behavior that is based on knowledge will be more lasting than behavior that is not based on knowledge. A critical indicator in nursing health service standards is preventing the occurrence of misconduct that can result in patient injury. Therefore, the knowledge that continues to be updated will be very important. The nurse can get knowledge from learning activities, individually and in teams. Environmental factors and leadership support the process of collective learnings and practices to improve team works and outcomes of the organization (Singer dkk., 2015). The knowledge about the culture of patient safety improve the quality of hospital services (Andri \& Soewondo, 2018).

Knowledge has a significant effect on the quality of work-life and its impact on the performance of nurses in the application of the patient safety system. Knowledgeable nurses are expected to be able to create useful interactions between nurses and be able to create conducive working conditions, to grow the comfort of the work environment, so that the impact on increasing enthusiasm to work. Besides, nurses who have worked comfortably will 
also give a high enough commitment to the hospital. Nurses who have a good quality of work-life will have an impact on improving nurse performance in the application of patient safety systems. Therefore, the company must play an active role in encouraging the development of quality work life for nurses by providing opportunities for employees to develop themselves through training programs and participate in every decision related to their work. A nurse who has a good commitment to the hospital, the hospital management needs to provide compensation in the form of opportunities to develop themselves and authority more flexible in making decisions, so that it will have an impact on improving performance (Ursoniu et al., 2012).

Nurse's performance is also influenced by motivation, work discipline, work facilities, and also the benefits of services provided. Azwar, 2011 mentioned that attitudes would be formed from social interactions experienced by individuals, in social interactions, there will be a relationship of mutual influence among individuals so that reciprocity will occur which also influences the pattern of individuals with the environment and psychology around them. In general, a person's attitude is influenced by the perceptions of each individual towards the object of attitude with what is seen and known, which later affects one's actions. In addition to perception, personal experience is one of the factors that influence attitudes. He stated, the basis for forming attitudes, the personal experience must leave a strong impression. Attitudes will be easier to form if personal experience occurs in situations involving emotional factors. Someone who has personal experience served and cared by a nurse will have a distinct impression in providing better service compared to nurses who do not have personal experience so that the attitude in providing services to patients is much different. Attitudes can influence the performance of nurses through the variable quality of work life. Nurses who have a positive attitude affect the performance of nurses in implementing a patient safety system.

Attitudes have a significant effect on the quality of work-life and have an impact on the performance of nurses in the application of the patient safety system at the hospital. From the respondent's answer to the question about patient safety, the highest trend value on the IPSG3 indicator, namely high caution in giving medicines to patients. 21 out of 40 nurses answered strongly agree that giving drugs to patients requires great attention and caution. It means that most nurses have a positive attitude to prevent mistakes in giving medicines to patients. Careful efforts in applying patient safety will have a positive impact on the quality of nursing services provided.

Attitude is a tendency to act from an individual, in the form of an instant reaction to a stimulus or a particular object (Sunaryo, 2004), one form of which is a positive attitude (pleasure), and a negative attitude (feeling displeased). Emotional reactions are much influenced by what is believed to be true of the object of attitude. Someone who has a positive attitude can provide a good quality of work-life, and vice versa, someone who has a negative attitude will also affect the quality of work-life negatively - knowledge gained from sharing experiences from other nurses or other hospitals. 


\section{CONCLUSION}

In conclusion, the higher a nurse's knowledge, the performance of patient safety implementation will be increased. Nurses who have a good quality of work-life will have an impact on improving nurse performance in the application of patient safety systems. Attitudes can also have an impact on improving performance indirectly through the quality of work-life. Positive nurses' attitudes and will be able to help achieve patient safety.

\section{REFERENCES}

Almaramhy, H., Al-Shobaili, H., El-Hadary, K., \& Dandash, K. (2011). Knowledge and Attitude Towards Patient Safety Among a Group of Undergraduate Medical Students in Saudi Arabia. International Journal of Health Sciences, 5(1), 59-67.

Andri, L. P., \& Soewondo, P. (2018). Nurses' Perception of Patient Safety Culture in the Hospital Accreditation Era: A Literature Review | KnE Life Sciences [Http://dx.doi.org/10.18502/kls.v4i9.3558].

https://knepublishing.com/index.php/Kne-Life/article/view/3558/7450

Bawelle, S. C., Sinolungan, J. S. V., \& Hamel, R. (2013). Hubungan Pengetahuan Dan Sikap Perawat Dengan Pelaksanaaan Keselamatan Pasien (Patient Safety) Di Ruang Rawat Inap Rsud Liun Kendage Tahuna. Jurnal Keperawatan, 1(1), Article 1. https://doi.org/10.35790/jkp.v1i1.2237

Brasaite, I., Kaunonen, M., Martinkenas, A., \& Suominen, T. (2016). Health care professionals' attitudes regarding patient safety: Cross-sectional survey. BMC Research Notes, 9(1). https://doi.org/10.1186/s13104-016-1977-7

Chan, K. W., \& Wyatt, T. A. (2007). Quality of Work Life: A Study of Employees in Shanghai, China. Asia Pacific Business Review, 13(4), 501-517. https://doi.org/10.1080/13602380701250681

Elden, N. M. K., \& Ismail, A. (2016). The Importance of Medication Errors Reporting in Improving the Quality of Clinical Care Services. Global Journal of Health Science, 8(8), 243-251. https://doi.org/10.5539/gjhs.v8n8p243

Ghozali, I. (2013). Aplikasi Analisis Multivariate Dengan Program IBM SPSS 21 Update PLS Regresi.

Gunawan, G., Harijanto, H., \& Harijanto, T. (2015). Analisis Rendahnya Laporan Insiden Keselamatan Pasien di Rumah Sakit. Jurnal Kedokteran Brawijaya, 28(2), 206-213. https://doi.org/10.21776/ub.jkb.2015.028.02.16

Hariyati et al. (2017). Correlation between Career Ladder, Continuing Professional Development and Nurse Satisfaction: A Case Study in Indonesia - ProQuest. Https://EResources.Perpusnas.Go.Id:2057/Docview/1988003496?Pq-Origsite=summon. https://e-resources.perpusnas.go.id:2057/docview/1988003496?pq-origsite=summon

Kahya, E., \& Oral, N. (2018). Measurement of clinical nurse performance: Developing a tool including contextual items. Journal of Nursing Education and Practice, 8(6), 112. https://doi.org/10.5430/jnep.v8n6p112 
Levine, M. F., Taylor, J. C., \& Davis, L. E. (1984). Defining Quality of Work Life.

Mwachofi, A., Walston, S. L., \& Al-Omar, B. A. (2011). Factors affecting nurses' perceptions of patient safety. International Journal of Health Care Quality Assurance, 24(4), 274-283. https://doi.org/10.1108/09526861111125589

Singer, S. J., Benzer, J. K., \& Hamdan, S. U. (2015). Improving health care quality and safety: The role of collective learning. Journal of Healthcare Leadership, 7, 91-107. https://doi.org/10.2147/JHL.S70115

Wara, N. G., Rampengan, S. H., \& Korompis, M. (2018). Correlation between Quality of Work Life (QWL) with Nurse productivity in inpatient room Bhayangkara Tk III Hospital Manado. Bali Medical Journal, 7(2), 385. https://doi.org/10.15562/bmj.v7i2.1018

WHO. (2017). WHO | The third WHO Global Patient Safety Challenge: Medication Without Harm. WHO. http://www.who.int/patientsafety/medication-safety/en/ 